\title{
Diversity and Enzymatic Profiling of Halotolerant Micromycetes from Sebkha El Melah, a Saharan Salt Flat in Southern Tunisia
}

\author{
Atef Jaouani, ${ }^{1}$ Mohamed Neifar, ${ }^{1}$ Valeria Prigione, ${ }^{2}$ Amani Ayari, ${ }^{1}$ \\ Imed Sbissi, ${ }^{1}$ Sonia Ben Amor, ${ }^{1}$ Seifeddine Ben Tekaya, ${ }^{1}$ Giovanna Cristina Varese, ${ }^{2}$ \\ Ameur Cherif, ${ }^{3}$ and Maher Gtari ${ }^{1}$ \\ ${ }^{1}$ Laboratoire Microorganismes et Biomolécules Actives, Faculté des Sciences de Tunis, Université Tunis El Manar, Campus Universitaire, \\ 2092 Tunis, Tunisia \\ ${ }^{2}$ Dipartimento di Scienze della Vita e Biologia dei Sistemi, Università degli Studi di Torino, Viale Mattioli 25, 10125 Torino, Italy \\ ${ }^{3}$ Laboratoire Biotechnologie et Valorisation des Bio-Géo Ressources, Institut Supérieur de Biotechnologie de Sidi Thabet, \\ Université La Manouba, 2020 Sidi Thabet, Tunisia
}

Correspondence should be addressed to Atef Jaouani; atef.jaouani@issbat.rnu.tn

Received 2 May 2014; Accepted 28 June 2014; Published 16 July 2014

Academic Editor: Sara Borin

Copyright (C) 2014 Atef Jaouani et al. This is an open access article distributed under the Creative Commons Attribution License, which permits unrestricted use, distribution, and reproduction in any medium, provided the original work is properly cited.

Twenty-one moderately halotolerant fungi have been isolated from sample ashes collected from Sebkha El Melah, a Saharan salt flat located in southern Tunisia. Based on morphology and sequence inference from the internal transcribed spacer regions, $28 \mathrm{~S}$ rRNA gene and other specific genes such as $\beta$-tubulin, actin, calmodulin, and glyceraldehyde-3-phosphate dehydrogenase, the isolates were found to be distributed over 15 taxa belonging to 6 genera of Ascomycetes: Cladosporium $(n=3)$, Alternaria $(n=4)$, Aspergillus ( $n=3)$, Penicillium $(n=5)$, Ulocladium $(n=2)$, and Engyodontium $(n=2)$. Their tolerance to different concentrations of salt in solid and liquid media was examined. Excepting Cladosporium cladosporioides JA18, all isolates were considered as alkalihalotolerant since they were able to grow in media containing $10 \%$ of salt with an initial $\mathrm{pH} 10$. All isolates were resistant to oxidative stresses and low temperature whereas 5 strains belonging to Alternaria, Ulocladium, and Aspergillus genera were able to grow at $45^{\circ} \mathrm{C}$. The screening of fungal strains for sets of enzyme production, namely, cellulase (CMCase), amylase, protease, lipase, and laccase, in presence of $10 \% \mathrm{NaCl}$, showed a variety of extracellular hydrolytic and oxidative profiles. Protease was the most abundant enzyme produced whereas laccase producers were members of the genus Cladosporium.

\section{Introduction}

Sebkhas are salt flats occurring on arid coastline in North Africa, Arabia, Baja California, and Shark Bay Australia [1]. They are considered among the most poikilotopic environments and characterized by extreme salt concentrations and electromagnetic radiation exposure together with low water and nutrient availabilities [2]. Regarded as detrimental to "normal subsistence," organisms copying such conditions to survive and thrive are designed extremophiles [3]. Beside halophytes plants and algae, the mostly diverse dwellers of sebkhas being unveiled are members of bacterial, archaeal, and fungal ranks [4-8]. Members of fungi kingdom recovered from extreme environments such as sebkhas' have shed light on two promising viewpoints: first, as model for deciphering stress adaptation mechanisms in eukaryotes [9] and secondary, as novel and largely unexplored materials for the screening of novel bioactive natural products [10]. Over the past decade, there is an increased awareness for new hydrolytic enzymes useful under nonconventional conditions [11].

Sebkha El Melah, a Saharan salt flat of southern Tunisia, has an area of approximately $150 \mathrm{~km}^{2}$ and the level is slightly below the sea. Fluvial basin excavation of Sebkha El Melah appeared at the beginning of the Würmian Quaternary period [12]. Around 40,000 BP the lagoon was highly desalinated by freshwater arrivals. At the upper Würm, seawater withdrew and the basin evolves to a temporary lake or 
continental sebkha. More recently, around 8000 years BP, the lagoon evolved into an evaporite basin. The sebkha sediments are composed of several saliferous layers of rock salt and gypsum (calcium sulfate) and/or polyhalite (sulfate of potassium, calcium, and magnesium) [12]. Here we report the isolation of moderately halotolerant fungi from Sebkha El Melah. Strains have been identified based on morphological and molecular markers and their resistance to salt, thermal, alkaline, and oxidative stresses was assessed. Their ability to produce different hydrolytic and oxidative enzymes under salt stress was also evaluated.

\section{Material and Methods}

2.1. Sampling Site Description and Fungal Isolation. Three locations from the Sebkha El Melah margins (L1: $33^{\circ} 23^{\prime} 01.1^{\prime \prime} \mathrm{N} 10^{\circ} 54^{\prime} 56.8^{\prime \prime} \mathrm{E}$; L2: $33^{\circ} 21^{\prime} 42.1^{\prime \prime} \mathrm{N} 10^{\circ} 55^{\prime} 05.5^{\prime \prime} \mathrm{E}$; and L3: $33^{\circ} 23^{\prime} 37.7^{\prime \prime} \mathrm{N} 10^{\circ} 53^{\prime} 40.2^{\prime \prime} \mathrm{E}$ ) were chosen for sampling (Figure 1). From each location, a composite sample was prepared aseptically from five subsamples $(1-10 \mathrm{~cm}$ deep) and collected from the arms and center of an X (each arm was $1 \mathrm{~m}$ in length) [13]. One $\mathrm{cm}$ soil from the ground surface was firstly removed to avoid contamination during sampling procedure. Samples were then transported to the laboratory in a cool box and stored at $4^{\circ} \mathrm{C}$ prior to processing.

Fungi were isolated on potato dextrose agar (PDA) containing $10 \%$ of $\mathrm{NaCl}$ and $0.05 \%$ of chloramphenicol using the soil plate method where few milligrams of sample were directly spread on the agar medium. This method has a slight edge over the dilution plate method since it allows higher total number of isolates and limits invasion by species which sporulate heavily [14].

2.2. Morphological and Molecular Identification. Isolated fungi were identified conventionally according to their macroscopic and microscopic features. After determination of their genera [15-17], they were transferred to the media recommended of selected genus monographs for species identification.

DNA extraction was achieved as described by Liu et al. [18]; the amplification of the internal transcribed spacer regions (nuclear-encoded 18S rRNA-ITS1-5.8S rRNA-ITS2$28 \mathrm{~S}$ rRNA) was performed using the couple of universal primers ITS1 ( $5^{\prime}$-TCC GTA GGT GAA CCT GCG G-3') and ITS4 (5'-TCC TCC GCT TAT TGA TAT GC- $\left.3^{\prime}\right)$ [19] and the thermal cycler conditions according to Luo and Mitchell [20]. PCR was carried out in $25 \mu \mathrm{L}$ volumes containing $2.5 \mu \mathrm{L}$ of $1 X$ PCR reaction buffer $(100 \mathrm{mM}$ Tris- $\mathrm{HCl}, 500 \mathrm{mM} \mathrm{KCl}$, $\mathrm{pH} 8.3$ ), $1.5 \mu \mathrm{L} \mathrm{MgCl}_{2}, 0.2 \mu \mathrm{mol} / \mathrm{L}$ (each) primer, $0.2 \mu \mathrm{mol} / \mathrm{L}$ (each) dNTP, and 2.5 units of Taq polymerase (Dream Taq, Fermentas) and $1 \mu \mathrm{L}$ of DNA template. Depending on the fungus genus, different gene sequences were amplified. For the Aspergillus flavus group, the calmodulin gene was amplified using the primers CL1 ( $5^{\prime}$-GARTWCAAGGAGGCCTTCTC- $3^{\prime}$ ) and CL2A ( $5^{\prime}$-TTTTGCATCATGAGTTGGAC$3^{\prime}$ ) according to Rodrigues et al. [21]; for the Cladosporium
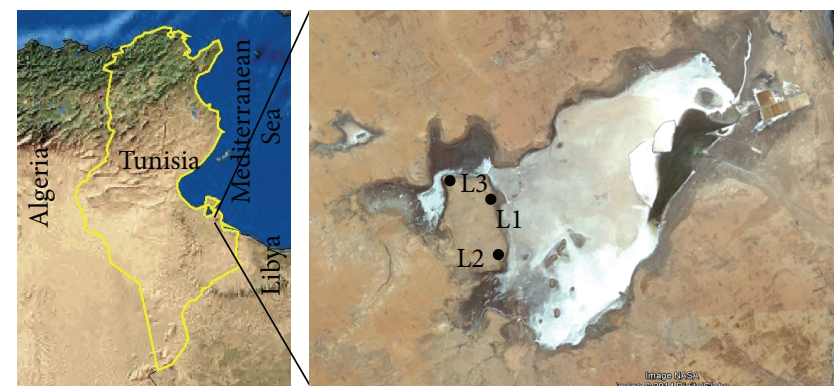

Figure 1: Map of Sebkha El Melah (Google Earth). L1, L2, and L3 indicate locations of sampling.

genus, the actin gene was amplified using the primers ACT512F ( $5^{\prime}$-ATGTGCAAGGCCGGTTTCGC- $\left.3^{\prime}\right)$ and ACT783R ( $5^{\prime}$-TACGAGTCCTTCTGGCCCAT- $3^{\prime}$ ) according to Bensch et al. [22]; for Alternaria genus, the glyceraldehyde3 -phosphate dehydrogenase gene was amplified using the primers GPD1 ( $5^{\prime}$-CAACGGCTTCGGTCGCATTG- $\left.3^{\prime}\right)$ and GPD2 (5'-GCCAAGCAGTTGGTTGTGC-3') according to Berbee et al. [23]; for Penicillium and Aspergillus genera, the $\beta$-tubulin gene was amplified using the primers $\mathrm{Bt} 2 \mathrm{a}$ ( $5^{\prime}$-GGTAACCAAATCGGTGCTGCTTTC- ${ }^{\prime}$ ) and Bt2B ( $5^{\prime}$-ACCCTCAGTGTAGTGACCCTTGGC- $3^{\prime}$ ) according to Glass and Donaldson [24].

The PCR products were purified with QIAquick Wizard PCR purification Kit (Promega) according to the manufacturer's instructions, and the sequences were determined by cycle sequencing using the Taq Dye Deoxy Terminator Cycle Sequencing kit (Applied Biosystems, HTDS, Tunisia) and fragment separation in an ABI PrismTM 3130 DNA sequencer (Applied Biosystems, HTDS, Tunisia). The sequences obtained were compared reference sequences in the NCBI GenBank database using the BLASTN search option [25].

\subsection{Effect of $p H$, Salinity, Temperature, and Oxidative Stress.} PDA medium was used to study the effect of different stresses on solid media. For oxidative stresses, $\mathrm{H}_{2} \mathrm{O}_{2}$ or paraquat was filter sterilized and added separately to melted PDA medium previously autoclaved. Paraquat is a redox-cycling agent widely used to generate reactive oxygen species and induce oxidative stress in bacteria [26] and fungi [27]. For pH stress, PDA medium was buffered with $100 \mathrm{mM}$ Glycine- $\mathrm{NaOH}$ to pH 10 before autoclaving. Salt stress in solid media was studied in PDA medium containing different concentrations of salts. The inoculated plates with $3 \mathrm{~mm}$ cylindrical mycelial plugs were then incubated at $30^{\circ} \mathrm{C}$ for oxidative, salt, and $\mathrm{pH}$ stresses and at $4^{\circ} \mathrm{C}$ and $45^{\circ} \mathrm{C}$ for thermal stresses, and radial growth was measured daily. Results were expressed as relative growth of fungal strains under different stresses as follows: (Colony diameter under stress/colony diameter without stress after 7 days incubation) $\times 100$.

The effect of salinity in liquid medium was carried out in Biolog system, a commercially redox based test (Biolog Inc., Hayward, CA). Malt extracts (2\%) containing 0\%, 5\%, 10\%, $15 \%$, and $20 \%$ of salt were inoculated by a suspension of spores 
and fragmented mycelium according to the supplier's instructions in 96-well microtiter plates. After 15 days incubation at $30^{\circ} \mathrm{C}$, the numeric results were extracted using PM Data Analysis 1.3 software. The fungal growth was assimilated to the reduction of the redox indicator. The ability of the fungus to grow in the presence of salt was expressed as the ratio of kinetic curve surface under stress versus without stress.

2.4. Extracellular Enzymes Production Profiling. The capacity of fungal isolates to produce extracellular enzymes, namely, amylase, cellulase, protease, laccase and lipase, was assayed in the presence of $10 \%$ of $\mathrm{NaCl}$. Inoculation was made by transferring $3 \mathrm{~mm}$ of cylindrical mycelial plugs on the corresponding media. Amylase production was assayed on PDA containing 1\% soluble starch. Enzyme production is shown by the presence of clear halo when iodine was poured onto the plates. Cellulase production was tested on PDA medium containing $1 \%$ of carboxymethylcellulose. The presence of activity is reflected by a clear halo on red background after flooding the plates with $0.2 \%$ Congo red for $30 \mathrm{~min}$. Protease production was revealed on skim milk agar by the appearance of a clear zone corresponding to casein hydrolysis/solubilization surrounding the microbial colony. The laccase production was detected on PDA medium containing $5 \mathrm{mM}$ of 2,6 dimethoxyphenol (DMP). Oxidation of the substrate is indicated by the appearance of brown color. Lipase production was tested on PDA medium containing $10 \mathrm{~mL} / \mathrm{L}$ of Tween 20 and $0.1 \mathrm{~g} / \mathrm{L}$ of $\mathrm{CaCl}_{2}$. Positive reaction is accompanied by the presence of precipitates around the fungal colony. The enzymes production was expressed as activity ratio (PR) which corresponds to the activity diameter (halo of enzymatic reaction) divided by the colony diameter after 7 days incubation at $30^{\circ} \mathrm{C}$.

2.5. Statistical Analysis. The data presented are the average of the results of at least three replicates with a standard error of less than $10 \%$.

\section{Results}

3.1. Isolation and Identification of Halotolerant Fungi. Twenty-one fungal isolates were obtained on halophilic medium containing $10 \% \mathrm{NaCl}$ and subjected to morphological and molecular identification. Seventeen strains were identified at genus level based on 28S rRNA gene sequences, while four were identified based on ITS regions. Final assignment was based on combination of morphological and $\beta$-tubulin, actin, calmodulin, and glyceraldehyde-3phosphate dehydrogenase genes sequencing (Table 1). The 21 strains have been identified as Cladosporium cladosporioides $(n=2)$, Cladosporium halotolerans $(n=1)$, Cladosporium sphaerospermum $(n=2)$, Alternaria tenuissima $(n=1)$, Aspergillus flavus $(n=1)$, Aspergillus fumigatiaffinis $(n=1)$, Aspergillus fumigatus $(n=1)$, Penicillium canescens $(n=1)$, Penicillium chrysogenum $(n=3)$, Penicillium sp. $(n=1)$, Alternaria alternata $(n=3)$, Ulocladium consortiale $(n=1)$, Ulocladium sp. $(n=1)$, Engyodontium album $(n=1)$, and Embellisia phragmospora $(n=1)$ species. All the strains have been deposited at the Mycotheca Universitatis Taurinensis (MUT) in the University of Turin.

3.2. Salt Tolerance of Fungal Isolates. Salt tolerance of the fungal isolates was assessed on solid and liquid media for $\mathrm{NaCl}$ content ranging from 5 to $20 \%$. In solid media, salt tolerance was estimated as relative growth represented by the ratio of colony diameter under salt stress to that without salt stress. As illustrated in Table 2, all the isolated strains succeeded to grow in the presence of $10 \%$ of salt. While 19 isolates remain able to grow under $15 \% \mathrm{NaCl}$, only 7 isolates tolerated 20\% NaCl: Penicillium chrysogenum JA1 and JA22, Cladosporium halotolerans JA8, Cladosporium sphaerospermum JA2, Cladosporium cladosporioides JA18, Aspergillus flavus JA4, and Engyodontium album JA7.

When liquid cultures were used, fungal isolates seemed to become more sensitive to salt stress. Indeed, none of the strains was able to grow in the presence of $20 \% \mathrm{NaCl}$, whereas only 8 strains and 19 strains tolerated $15 \%$ and $10 \% \mathrm{NaCl}$, respectively (Table 2 ).

3.3. Alkaline, Temperature, and Oxidative Stress. Excepting Cladosporium cladosporioides JA18, all tested strains were able to grow at $\mathrm{pH} 10$. All isolates were able to grow at $4^{\circ} \mathrm{C}$ while only five strains Aspergillus fumigatus JA10, Aspergillus fumigatiaffinis JA11, Alternaria alternata JA23, Ulocladium consortiale JA12, and Ulocladium sp. JA17 showed a significant growth at $45^{\circ} \mathrm{C}$. All 21 strains tolerated oxidative stress generated by $10 \mathrm{mM} \mathrm{H}_{2} \mathrm{O}_{2}$ and $500 \mu \mathrm{M}$ paraquat (Table 3 ).

3.4. Enzymatic Profiling of Isolates. Among the 21 strains tested, 13 strains displayed at least one of the five-screened activities: protease, amylase, cellulase, lipase, and laccase, in the presence of $10 \% \mathrm{NaCl}$ (Table 4). Protease and amylase were the most abundant activities shown by 9 and 6 strains, respectively. Four strains belonging to Cladosporium and Penicillium genera produced laccase while Cladosporium sphaerospermum JA2, Aspergillus flavus JA4, and Engyodontium album JA7 were able to produce lipase. Cellulase activity was detected only in Penicillium sp. JA15.

\section{Discussion}

With regard to bacteria that have been well explored in southern desert region of Tunisia [28-31], data related to fungi are scarce and are limited to truffle and mycorrhiza, so far considered as real specialists of desert environments [32, 33]. To the best of our knowledge, this is the first report on the isolation and characterization of fungi from Tunisian desert and particularly from salt flat. A collection of 21 fungi isolates have been established from samples ashes collected from Sebkha El Melah. These alkalihalotolerant fungi have been assigned to 15 taxa belonging to 6 genera of Ascomycetes. Several studies showed that fungi belonging to Cladosporium, Alternaria, and Ulocladium genera were clearly predominant under desert and salty environments $[34,35]$. These fungi have in common thick-walled and strongly melanized spores which are important for $\mathrm{UV}$, radiation, and desiccation 


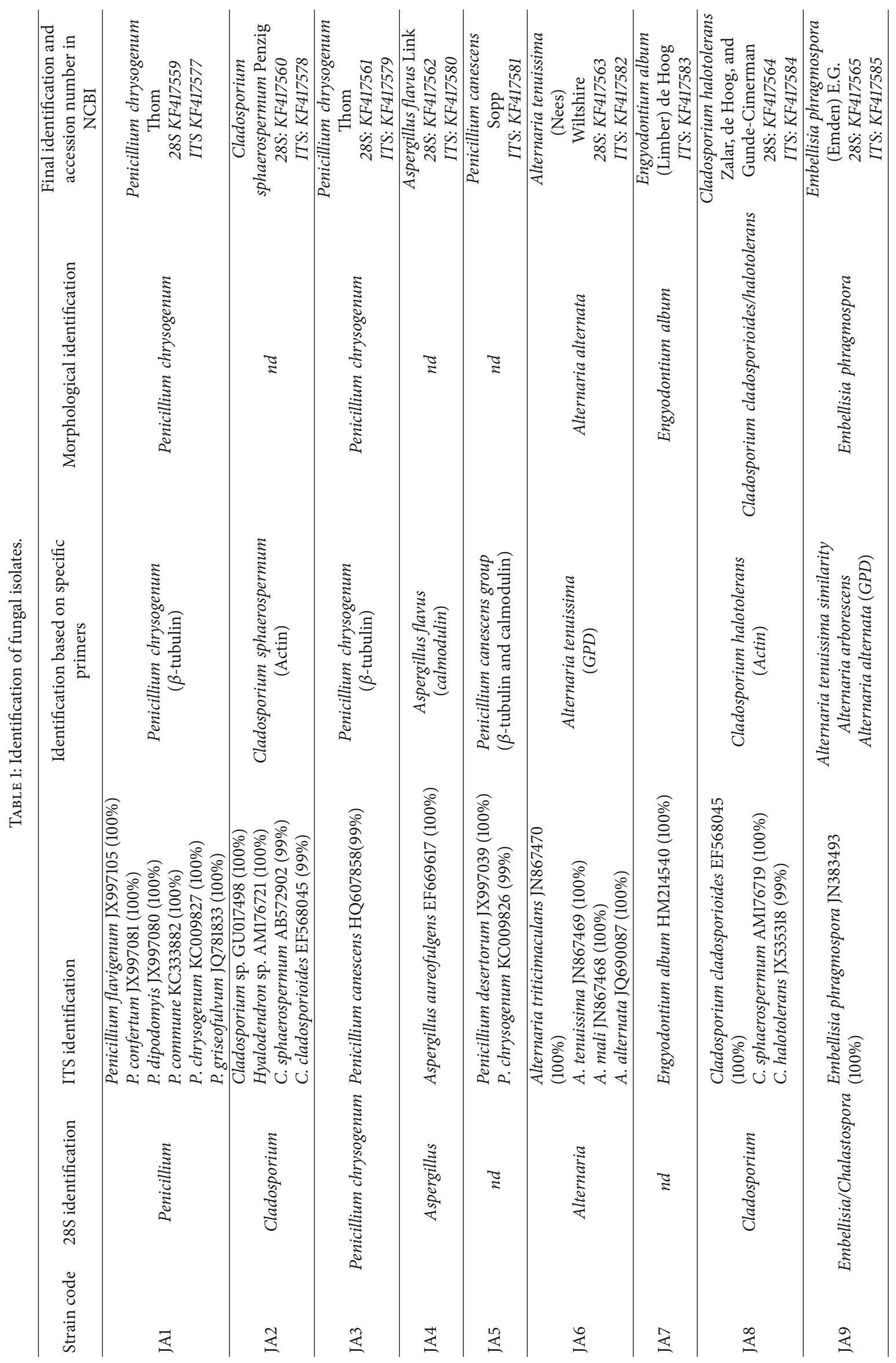




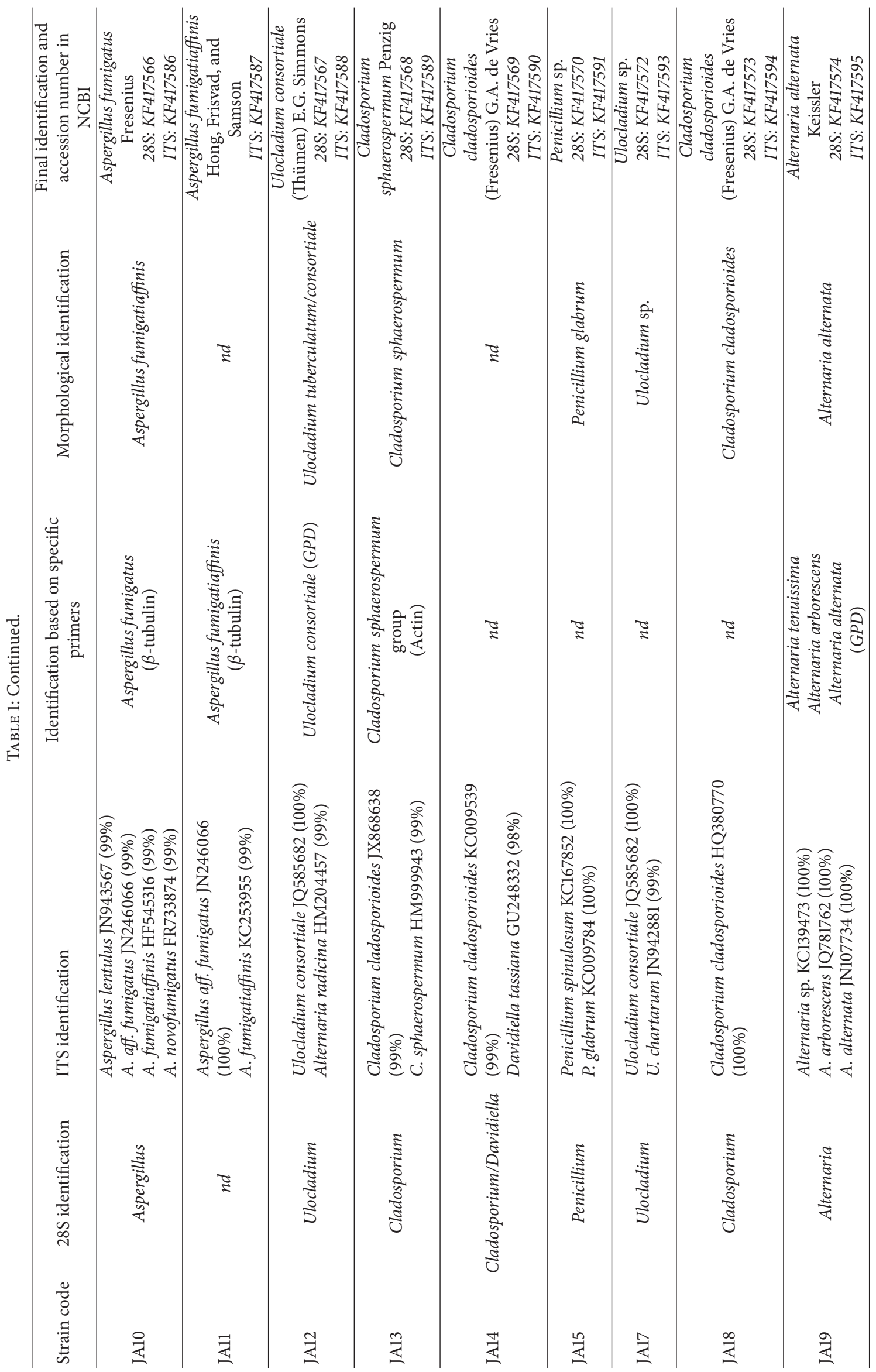




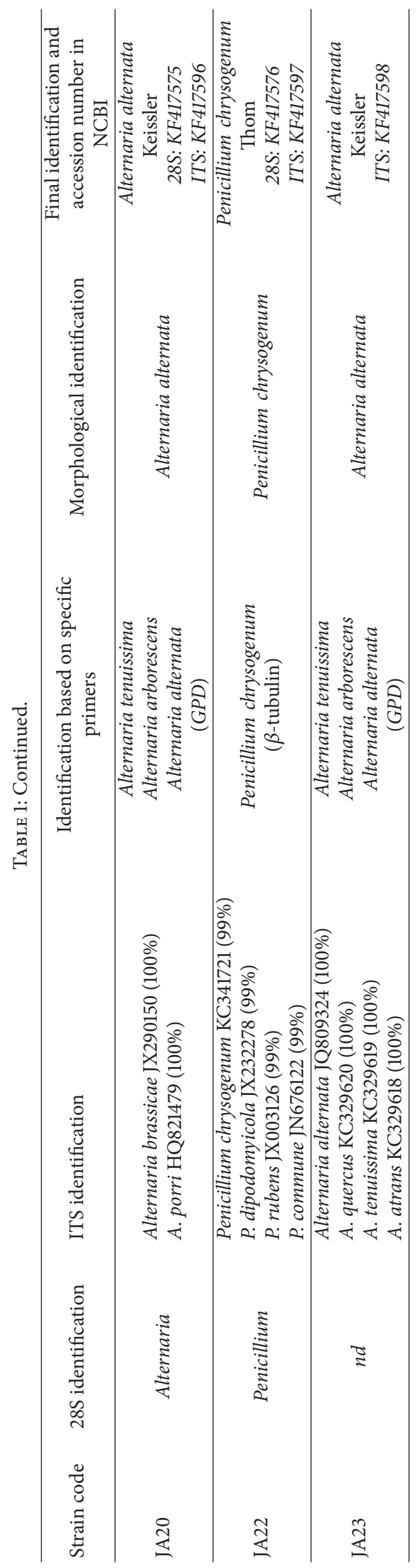


TABLE 2: Effect of salt concentration on fungal growth in solid and liquid media.

\begin{tabular}{|c|c|c|c|c|c|c|c|c|c|}
\hline \multirow{2}{*}{ Strain code } & \multirow{2}{*}{ Strain } & \multicolumn{4}{|c|}{ Solid media (1) } & \multicolumn{4}{|c|}{ Liquid media (2) } \\
\hline & & $5 \% \mathrm{NaCl}$ & $10 \% \mathrm{NaCl}$ & $15 \% \mathrm{NaCl}$ & $20 \% \mathrm{NaCl}$ & $5 \% \mathrm{NaCl}$ & $10 \% \mathrm{NaCl}$ & $15 \% \mathrm{NaCl}$ & $20 \% \mathrm{NaCl}$ \\
\hline JA1 & Penicillium chrysogenum & 74 & 72 & 60 & 18 & 83 & 54 & 10 & 0 \\
\hline JA3 & Penicillium chrysogenum & 100 & 72 & 37 & 0 & 96 & 46 & 11 & 0 \\
\hline JA22 & Penicillium chrysogenum & 100 & 82 & 41 & 25 & 90 & 46 & 0 & 0 \\
\hline AJ5 & Penicillium canescens & 70 & 30 & 20 & 0 & 79 & 44 & 0 & 0 \\
\hline JA15 & Penicillium sp. & 83 & 70 & 34 & 0 & 53 & 18 & 0 & 0 \\
\hline JA8 & Cladosporium halotolerans & 80 & 68 & 32 & 18 & 30 & 0 & 0 & 0 \\
\hline JA2 & Cladosporium sphaerospermum & 76 & 64 & 34 & 22 & 47 & 19 & 11 & 0 \\
\hline JA13 & Cladosporium sphaerospermum & 100 & 49 & 25 & 0 & 81 & 79 & 12 & 0 \\
\hline JA14 & Cladosporium cladosporioides & 40 & 30 & 10 & 0 & 0 & 0 & 0 & 0 \\
\hline JA18 & Cladosporium cladosporioides & 58 & 40 & 24 & 8 & 63 & 61 & 4 & 0 \\
\hline JA4 & Aspergillus flavus & 90 & 80 & 48 & 26 & 56 & 16 & 0 & 0 \\
\hline JA10 & Aspergillus fumigatus & 100 & 76 & 35 & 0 & 100 & 57 & 11 & 0 \\
\hline JA11 & Aspergillus fumigatiaffinis & 100 & 46 & 25 & 0 & 52 & 30 & 12 & 0 \\
\hline JA19 & Alternaria alternata & 52 & 38 & 24 & 0 & 57 & 9 & 0 & 0 \\
\hline JA20 & Alternaria alternata & 60 & 40 & 0 & 0 & 37 & 24 & 0 & 0 \\
\hline JA23 & Alternaria alternata & 100 & 68 & 20 & 0 & 65 & 12 & 0 & 0 \\
\hline JA6 & Alternaria tenuissima & 100 & 60 & 22 & 0 & 80 & 55 & 17 & 0 \\
\hline JA9 & Embellisia phragmospora & 94 & 50 & 10 & 0 & 78 & 26 & 0 & 0 \\
\hline JA12 & Ulocladium consortiale & 72 & 28 & 0 & 0 & 32 & 10 & 0 & 0 \\
\hline JA17 & Ulocladium sp. & 100 & 70 & 28 & 0 & 67 & 20 & 0 & 0 \\
\hline JA7 & Engyodontium album & 56 & 36 & 14 & 10 & 43 & 10 & 0 & 0 \\
\hline
\end{tabular}

(1) Relative growth on solid media after 7 days incubation $=(\varnothing$ colony under salt stress $/ \varnothing$ colony without salt stress $) \times 100$. (2) Relative growth in liquid media after 7 days incubation $=($ kinetic curve surface under salt stress/kinetic curve surface without salt stress $) \times 100$.

TABLE 3: Effect of alkaline, thermal, and oxidative stresses on fungal growth.

\begin{tabular}{|c|c|c|c|c|c|c|}
\hline \multirow{2}{*}{ Strain code } & \multirow{2}{*}{ Strain } & \multirow{2}{*}{$\begin{array}{c}\text { Alkaline stress (1) } \\
\text { pH } 10\end{array}$} & \multicolumn{2}{|c|}{ Thermal stress (2) } & \multicolumn{2}{|c|}{ Oxidative stress (3) } \\
\hline & & & $4^{\circ} \mathrm{C}$ & $45^{\circ} \mathrm{C}$ & $\mathrm{H}_{2} \mathrm{O}_{2}[10 \mathrm{mM}]$ & Paraquat $[500 \mu \mathrm{M}]$ \\
\hline JA1 & Penicillium chrysogenum & 43 & 39 & - & 66 & 74 \\
\hline JA3 & Penicillium chrysogenum & 42 & 50 & - & 84 & 71 \\
\hline JA22 & Penicillium chrysogenum & 47 & 45 & - & 68 & 53 \\
\hline JA5 & Penicillium canescens & 26 & 28 & - & 59 & 63 \\
\hline JA15 & Penicillium sp. & 43 & 100 & - & 100 & 100 \\
\hline JA8 & Cladosporium halotolerans & 34 & 26 & - & 44 & 40 \\
\hline JA2 & Cladosporium sphaerospermum & 21 & 24 & - & 52 & 48 \\
\hline JA13 & Cladosporium sphaerospermum & 21 & 43 & - & 55 & 44 \\
\hline JA14 & Cladosporium cladosporioides & 34 & 38 & - & 20 & 31 \\
\hline JA18 & Cladosporium cladosporioides & - & 41 & - & 18 & 16 \\
\hline JA4 & Aspergillus flavus & 46 & 22 & - & 47 & 39 \\
\hline JA10 & Aspergillus fumigatus & 89 & 41 & 61 & 100 & 100 \\
\hline JA11 & Aspergillus fumigatiaffinis & 94 & 26 & 100 & 100 & 100 \\
\hline JA19 & Alternaria alternata & 49 & 35 & - & 69 & 89 \\
\hline JA20 & Alternaria alternata & 58 & 48 & - & 100 & 100 \\
\hline JA23 & Alternaria alternata & 100 & 83 & 40 & 57 & 52 \\
\hline JA6 & Alternaria tenuissima & 57 & 30 & - & 81 & 100 \\
\hline JA9 & Embellisia phragmospora & 58 & 67 & - & 100 & 100 \\
\hline JA12 & Ulocladium consortiale & 44 & 37 & 36 & 56 & 100 \\
\hline JA17 & Ulocladium sp. & 93 & 28 & 100 & 81 & 100 \\
\hline JA7 & Engyodontium album & 34 & 18 & - & 66 & 53 \\
\hline
\end{tabular}

Relative growth of fungal strains under different stresses after 7 days incubation was expressed as follows: (1) ( $\varnothing$ colony at $\mathrm{pH} 10 / \varnothing$ colony at $\mathrm{pH} 5) \times 100 ;(2)$ $\left(\varnothing\right.$ colony at $45^{\circ} \mathrm{C}$ or $4^{\circ} \mathrm{C} / \varnothing$ colony at $\left.30^{\circ} \mathrm{C}\right) \times 100$; (3) ( $\varnothing$ colony with $\mathrm{H}_{2} \mathrm{O}_{2}$ or paraquat/ $\varnothing$ colony without stress $) \times 100$. - : not significant growth 
TABLE 4: Enzymes activities of fungal isolates in the presence of $10 \% \mathrm{NaCl}$.

\begin{tabular}{lccccc}
\hline Strain code & Strain & Protease & Amylase & Cellulase & Lipase \\
\hline JA1 & Penicillium chrysogenum & ++ & + & - & Laccase \\
JA3 & Penicillium chrysogenum & ++ & - & - & - \\
JA22 & Penicillium chrysogenum & + & + & - & - \\
AJ5 & Penicillium canescens & - & - & - & - \\
JA15 & Penicillium sp. & - & - & - & - \\
JA8 & Cladosporium halotolerans & + & - & - & - \\
JA2 & Cladosporium sphaerospermum & +++ & - & - & + \\
JA13 & Cladosporium sphaerospermum & - & + & - & - \\
JA14 & Cladosporium cladosporioides & + & + & - \\
JA18 & Cladosporium cladosporioides & - & - & - \\
JA4 & Aspergillus flavus & + & - & - & + \\
JA10 & Aspergillus fumigatus & - & - & - \\
JA11 & Aspergillus fumigatiaffinis & - & - & - \\
JA19 & Alternaria alternata & - & - & - \\
JA20 & Alternaria alternata & - & - & - \\
JA23 & Alternaria alternata & - & - & - \\
JA6 & Alternaria tenuissima & + & - & - \\
JA9 & Embellisia phragmospora & - & - & - \\
JA12 & Ulocladium consortiale & - & - & - \\
JA17 & Ulocladium sp. & - & - & - \\
JA7 & Engyodontium album & + & - & - \\
\hline AR: & - & - & - \\
\end{tabular}

AR: activity ratio $=(\varnothing$ activity $/ \varnothing$ colony $) .-$ no activity; +: $\mathrm{AR}<1 ;++: 1<\mathrm{AR}<2 ;+++: 2<\mathrm{AR}<3$.

tolerance [10]. On the other hand, Molitoris et al. [36] reported that other halotolerant and halophilic fungi such as Aspergillus and Cladosporium spp. are predominant in saline desert soil of Dead Sea. Many Aspergillus species have been also reported to constitute dominant fungi in desert of Saudi Arabia and Libya [37, 38], and halotolerant species, including Aspergillus spp., Penicillium spp., and Cladosporium sphaerospermum, have been consistently isolated from hypersaline environments around the globe [39]. In this study, contrary to many reports on hypersaline environments, no species belonging to the genera Eurotium, Thrimmatostroma, Emericella, and Phaeotheca [9] have been obtained, probably because of the initial alkaline $\mathrm{pH}$ of the Sebkha El Melah salt lake. Actually, the effect of $\mathrm{pH}$ on the fungal diversity is controversial. Misra [40] observed that fungal diversity varies with the $\mathrm{pH}$ while other investigators found no significant effect of $\mathrm{pH}$ values of water and soil habitats on fungal occurrence [41]. It is more likely that the number of the isolated fungi is directly correlated to the organic matter content of water, mud, and soil samples [42].

Beside the identification of the recovered fungal isolates from Sebkha El Melah, the second goal of the current study was the detection of some of their physiological and biochemical features. This allows understanding ecological adaptation to extreme environment and predicts some biotechnological usage. The 21 strains have been screened for tolerance to extreme $\mathrm{NaCl}$ concentrations, basic $\mathrm{pH}$, temperature, and oxidative stress and for the production of important enzymatic activities in presence of $10 \% \mathrm{NaCl}$.

Excepting Cladosporium cladosporioides JA18, all isolates obtained in this study can be considered as moderately haloalkaliphilic fungi as deduced from their ability to grow at $\mathrm{pH} 10$ and $10 \%$ of $\mathrm{NaCl}$. However, the isolates were able to grow when salt was not added to their growing media. Excepting some Wallemia ichthyophaga the most strictly halophilic fungus [43], all other fungal strains known to date are able to grow without salt, a fact confirmed in our study. However, gradual decrease in fungal growth was observed with the increasing of salt concentration in the culture medium. Nineteen strains remain able to grow under $15 \%$ of $\mathrm{NaCl}$, whereas 7 strains were able to tolerate $20 \%$ of $\mathrm{NaCl}$. This result was confirmed by salt tolerance assay in liquid media as estimated by Biolog system. It is noteworthy that fungi were more sensitive to salt stress in liquid media than in solid media. This could be explained by the alteration of the osmotic gradient, forcing the fungi to expend more energy in the osmoregulatory processes, resulting in slower growth [44]. Moreover, at higher salt concentration death occurs.

Regarding the stress of $\mathrm{pH}$, the capacity of the majority of isolates to growth at $\mathrm{pH} 10$ implies firstly that some habitats in the salt lake may have a varying $\mathrm{pH}$ and secondly that fungi can tolerate a wide $\mathrm{pH}$ range. Prima facie, the overall results in solid and liquid media showed that Penicillium chrysogenum JA1 and JA3, Cladosporium sphaerospermum JA2 and JA13, Cladosporium cladosporioides JA18, Aspergillus fumigatus JA10, Aspergillus fumigatiaffinis JA11, and Alternaria tenuissima JA6 are the most alkalihalotolerant isolates in this study.

The tolerance of the strains to extreme $45^{\circ} \mathrm{C}$ was tested and results indicated that Aspergillus fumigatus JA10, Alternaria alternata JA23, Ulocladium sp. JA17, and Aspergillus fumigatiaffinis JA11 were able to grow. Of particular interest, the latter two strains retained $100 \%$ of the growth rate 
and biomass production as estimated by colony diameter. Moreover, their ability to grow at low temperature may allow them to better adapt to the big temperature fluctuation in desert environments. Additionally, exposure to substrates generating oxidative stress such as $\mathrm{H}_{2} \mathrm{O}_{2}$ at $10 \mathrm{mM}$ and paraquat at $500 \mu \mathrm{M}$ did not alter significantly the growth of almost tested strains demonstrating their ability to tolerate oxidative stress. These findings may explain their presence in desert regions that are considered amongst the most stressful environments on Earth because of the high UV radiation, desiccation, increased salinity, low nutrient availability, seasonal and daily temperature variation, and solar irradiation $[6,10]$.

It has been postulated that microorganisms sharing a rich and particular extracellular enzymatic activities are common in harsh conditions characterizing their ecological habitat including high level of aridity, temperature, ionic strength, and particularly the low nutrient availability [31]. This implies the need by microorganisms for an effective utilization of each possible available organic compound [45]. Moreover, fungal isolates from hot desert were revealed to play an important role in seeds germination by breaking dormancy and increasing water uptake [46]. In the present study, the capacity of fungal isolates to produce extracellular enzymes was assayed in the presence of $10 \%$ of $\mathrm{NaCl}$. Enzymes tested were the following: amylase for degradation of starch, abundant carbohydrate polymer in many plant tissues; protease for degradation of plant and animal proteins; cellulase which hydrolyses the cellulose, the main component of wood, ubiquitous substrate for fungi; and finally the laccase involved in plant material delignification and in the synthesis of the melanin and related compounds to protect fungi against radiation. Thirteen strains displayed high productions at least for one of the five-screened activities while no clear correlation of enzyme production profile with fungal systematic groups was noted. The abundance of protease activity is in line with previous data on fungal isolates from extreme environments showing high caseinase activities with little effect of salinity and temperature on enzyme production [36]. The relative limited number of isolates displaying cellulase, amylase, lipase, and laccase activities suggests that high concentration of salt may have an adverse effect on enzyme production and/or activity. Their energy was probably oriented to avoid salt stress due to $10 \% \mathrm{NaCl}$ rather than the production of bioactive extrolites [47]. However, not detecting the enzyme is not absolute confirmation of an isolate inability to produce it. It could also mean that the enzyme was not released from the mycelium or that the medium is inadequate for its detection [48]. Laccase production in the presence of $10 \%$ of salt by the Cladosporium group may be of biotechnological interest, for example, in mycoremediation of high salty environments contaminated by organic pollutants.

In conclusion, fungal community described in this study was similar to those reported in inhospitable habitats char acterized by limitation of nutrients, moisture deficit, and exposure to high solar radiation. Further studies are needed in order to elucidate their biogeochemical roles in such an extreme environment and to exploit their promising potential to produce new biomolecules such as enzymes and protective agents against oxidative stress.

\section{Conflict of Interests}

The authors declare that there is no conflict of interests regarding the publication of this paper.

\section{Acknowledgments}

The authors acknowledge the financial support from the European Union in the ambit of the Project BIODESERT (EU FP7-CSA-SA REGPOT-2008-2, Grant agreement no. 245746) and the Tunisian Ministry of Higher Education and Scientific Research in the ambit of the laboratory Project LR MBA20. Atef Jaouani wants to thank the Tunisian Society for Microbial Ecology (ATEM) for supporting publication fees of this work.

\section{References}

[1] J. K. Warren, "Sabkhas, saline mudflats and pans," in Evaporites: Sediments, Resources and Hydrocarbons, pp. 139-220, Springer, Berlin, Germany, 2006.

[2] A. A. Gorbushina and W. E. Krumbein, "Rock dwelling fungal communities: diversity of life styles and colony structure," in Journey to Diverse Microbial Worlds, J. Seckbach, Ed., pp. 317334, Kluwer Academic Publishers, Amsterdam, The Netherlands, 2000.

[3] L. J. Rothschild and R. L. Mancinelli, "Life in extreme environments," Nature, vol. 409, no. 6823, pp. 1092-1101, 2001.

[4] S. B. Humayoun, N. Bano, and J. T. Hollibaugh, "Depth distribution of microbial diversity in mono lake, a meromictic soda lake in California," Applied and Environmental Microbiology, vol. 69, no. 2, pp. 1030-1042, 2003.

[5] C. Demergasso, E. O. Casamayor, G. Chong, P. Galleguillos, L. Escudero, and C. Pedrós-Alió, "Distribution of prokaryotic genetic diversity in athalassohaline lakes of the Atacama Desert, Northern Chile," FEMS Microbiology Ecology, vol. 48, no. 1, pp. 57-69, 2004.

[6] N. Gunde-Cimerman, A. Oren, and A. Plemenitaš, "Adaptation to life in high salt concentrations," in Archaea, Bacteria, and Eukarya, p. 576, Springer, Dordrecht, The Netherlands, 2005.

[7] L. Maturrano, F. Santos, R. Rosselló-Mora, and J. Antón, "Microbial diversity in Maras salterns, a hypersaline environment in the Peruvian Andes," Applied and Environmental Microbiology, vol. 72, no. 6, pp. 3887-3895, 2006.

[8] Q. Wu, G. Zwart, M. Schauer, M. Kamst-van Agterveld, and M. Hahn, "Bacterioplankton community composition along a salinity gradient of sixteen high-mountain lakes located on the Tibetan Plateau, China," Applied and Environmental Microbiology, vol. 72, no. 8, pp. 5478-5485, 2006.

[9] C. Gostinčar, M. Grube, S. De Hoog, P. Zalar, and N. GundeCimerman, "Extremotolerance in fungi: evolution on the edge," FEMS Microbiology Ecology, vol. 71, no. 1, pp. 2-11, 2010. 
[10] K. Sterflinger, D. Tesei, and K. Zakharova, "Fungi in hot and cold deserts with particular reference to microcolonial fungi," Fungal Ecology, vol. 5, no. 4, pp. 453-462, 2012.

[11] M. J. Liszka, M. E. Clark, E. Schneider, and D. S. Clark, "Nature versus nurture: developing enzymes that function under extreme conditions," Annual Review of Chemical and Biomolecular Engineering, vol. 3, pp. 77-102, 2012.

[12] J. P. Perthuisot, La Sebkha El Melah de Zarzis: genèse et évolution d'un bassin salin paralique; Les gisements néolithiques des abords de la Sebkha el Melah, vol. 9 of de Travaux du Laboratoire de géologie/École normale supérieure, École Normale Supérieure, 1975.

[13] I. cLellan, A. Varela, M. Blahgen et al., "Harmonisation of physical and chemical methods for soil management in Cork Oak forests-lessons from collaborative investigations," African Journal of Environmental Science and Technology, vol. 7, no. 6, pp. 386-401, 2013.

[14] J. H. Warcup, "The soil-plate method for isolation of fungi from soil," Nature, vol. 166, no. 4211, pp. 117-118, 1950.

[15] K. H. Domsch, W. Gams, and T. H. Anderson, Compendium of Soil Fungi, Academic Press, London, UK, 1980.

[16] J. A. von Arx, The Genera of Fungi Sporulating in Pure Culture, J. Cramer, Vaduz, Germany, 1981.

[17] E. Kiffer and M. Morelet, Les deutéromycètes: Classification et clés d'identification gènérique, INRA Editions, Paris, France, 1997.

[18] D. Liu, S. Coloe, R. Baird, and J. Pedersen, "Rapid minipreparation of fungal DNA for PCR," Journal of Clinical Microbiology, vol. 38, no. 1, article 471, 2000.

[19] T. J. White, T. Bruns, S. Lee, and J. Talor, "Amplification and direct sequencing of fungal ribosomal RNA genes for phylogenetics," in PCR Protocols: A Guide to Methods and Applications, M. A. Innes, D. H. Gelfand, J. J. Sninsky, and T. J. White, Eds., pp. 315-322, Academic Press, New York, NY, USA, 1990.

[20] G. Luo and T. G. Mitchell, "Rapid identification of pathogenic fungi directly from cultures by using multiplex PCR," Journal of Clinical Microbiology, vol. 40, no. 8, pp. 2860-2865, 2002.

[21] P. Rodrigues, C. Santos, A. Venâncio, and N. Lima, "Species identification of Aspergillus section Flavi isolates from Portuguese almonds using phenotypic, including MALDI-TOF ICMS, and molecular approaches," Journal of Applied Microbiology, vol. 111, no. 4, pp. 877-892, 2011.

[22] K. Bensch, U. Braun, J. Z. Groenewald, and P. W. Crous, "The genus cladosporium," Studies in Mycology, vol. 72, pp. 1-401, 2012.

[23] M. L. Berbee, M. Pirseyedi, and S. Hubbard, "Cochliobolus phylogenetics and the origin of known, highly virulent pathogens, inferred from ITS and glyceraldehyde-3-phosphate dehydrogenase gene sequences," Mycologia, vol. 91, no. 6, pp. 964-977, 1999.

[24] N. L. Glass and G. C. Donaldson, "Development of primer sets designed for use with the PCR to amplify conserved genes from filamentous Ascomycetes," Applied and Environmental Microbiology, vol. 61, no. 4, pp. 1323-1330, 1995.

[25] S. F. Altschul, W. Gish, W. Miller, E. W. Myers, and D. J. Lipman, "Basic local alignment search tool," Journal of Molecular Biology, vol. 215, no. 3, pp. 403-410, 1990.

[26] H. M. Hassan and I. Fridovich, "Paraquat and Escherichia coli. Mechanism of production of extracellular superoxide radical," Journal of Biological Chemistry, vol. 254, no. 21, pp. 10846-10852, 1979.
[27] M. B. Angelova, S. B. Pashova, B. K. Spasova, S. V. Vassilev, and L. S. Slokoska, "Oxidative stress response of filamentous fungi induced by hydrogen peroxide and paraquat," Mycological Research, vol. 109, no. 2, pp. 150-158, 2005.

[28] A. de Groot, V. Chapon, P. Servant et al., "Deinococcus deserti sp. nov., a gamma-radiation-tolerant bacterium isolated from the Sahara Desert," International Journal of Systematic and Evolutionary Microbiology, vol. 55, no. 6, pp. 2441-2446, 2005.

[29] A. Chanal, V. Chapon, K. Benzerara et al., "The desert of Tataouine: an extreme environment that hosts a wide diversity of microorganisms and radiotolerant bacteria," Environmental Microbiology, vol. 8, no. 3, pp. 514-525, 2006.

[30] M. Gtari, D. Daffonchio, and A. Boudabous, "Assessment of the genetic diversity of Frankia microsymbionts of Elaeagnus angustifolia L. plants growing in a Tunisian date-palm oasis by analysis of PCR amplified nifD-K intergenic spacer," Canadian Journal of Microbiology, vol. 53, no. 3, pp. 440-445, 2007.

[31] I. Essoussi, F. Ghodhbane-Gtari, H. Amairi et al., "Esterase as an enzymatic signature of Geodermatophilaceae adaptability to Sahara desert stones and monuments," Journal of Applied Microbiology, vol. 108, no. 5, pp. 1723-1732, 2010.

[32] I. Sbissi, M. Neffati, A. Boudabous, C. Murat, and M. Gtari, "Phylogenetic affiliation of the desert truffles Picoa juniperi and Picoa lefebvrei," Antonie van Leeuwenhoek, vol. 98, no. 4, pp. 429-436, 2010.

[33] I. Sbissi, F. Ghodhbane-Gtari, M. Neffati, H. Ouzari, A. Boudabous, and M. Gtari, "Diversity of the desert truffle Terfezia boudieri chatin in southern Tunisia," Canadian Journal of Microbiology, vol. 57, no. 7, pp. 599-605, 2011.

[34] C. A. Conley, G. Ishkhanova, C. P. McKay, and K. Cullings, "A preliminary survey of non-lichenized fungi cultured from the hyperarid Atacama Desert of Chile," Astrobiology, vol. 6, no. 4, pp. 521-526, 2006.

[35] E. V. Smolyanyuk and E. N. Bilanenko, "Communities of halotolerant micromycetes from the areas of natural salinity," Microbiology, vol. 80, no. 6, pp. 877-883, 2011.

[36] H. P. Molitoris, A. S. Buchalo, I. Kurchenko et al., "Physiological diversity of the fIrst fIlamentous fungi isolated from the hypersaline Dead Sea," in Aquatic Mycology Across the Millennium, K. D. Hyde, W. H. Ho, and S. B. Pointing, Eds., vol. 5, pp. 55-70, Fungal Diversity Press, 2000.

[37] S. I. I. Abdel-Hafez, "Survey of the mycoflora of desert soils in Saudi Arabia," Mycopathologia, vol. 80, no. 1, pp. 3-8, 1982.

[38] A. H. M. El-Said and A. Saleem, "Ecological and physiological studies on soil fungi at Western Region, Libya," Mycobiology, vol. 36, pp. 1-9, 2008.

[39] P. Zalar, G. S. de Hoog, H.-J. Schroers, P. W. Crous, J. Z. Groenewald, and N. Gunde-Cimerman, "Phylogeny and ecology of the ubiquitous saprobe Cladosporium sphaerospermum, with descriptions of seven new species from hypersaline environments," Studies in Mycology, vol. 58, pp. 157-183, 2007.

[40] J. K. Misra, "Occurrence, distribution and seasonality of aquatic fungi as affected by chemical factors in six alkaline ponds of India," Hydrobiologia, vol. 97, no. 2, pp. 185-191, 1982.

[41] F. T. El-Hissy, S. A. El-Zayat, A. M. Khallil, and M. S. Massoud, "Aquatic fungi from the submerged mud of Aswan High Dam Lake," Microbiological Research, vol. 152, no. 1, pp. 27-32, 1997.

[42] A. M. Khallil, F. T. El-Hissy, and E. H. Ali, "Seasonal fluctuations of aquatic fungi recovered from Egyptian soil (Delta Region)," Journal of Basic Microbiology, vol. 35, no. 2, pp. 93-102, 1995. 
[43] P. B. Matheny, J. A. Gossmann, P. Zalar, T. K. A. Kumar, and D. S. Hibbett, "Resolving the phylogenetic position of the Wallemiomycetes: an enigmatic major lineage of Basidiomycota," Canadian Journal of Botany, vol. 84, no. 12, pp. 1794-1805, 2006.

[44] A. Blomberg and L. Adler, "Tolerence of fungi to NaCl," in Stress Tolerance of Fungi, D. Jennings, Ed., pp. 209-231, 1993.

[45] A. Oren, "Bioenergetic aspects of halophilism," Microbiology and Molecular Biology Reviews, vol. 63, no. 2, pp. 334-348, 1999.

[46] P. Delgado-Sánchez, M. A. Ortega-Amaro, J. F. JiménezBremont, and J. Flores, "Are fungi important for breaking seed dormancy in desert species? Experimental evidence in Opuntia streptacantha (Cactaceae)," Plant Biology, vol. 13, no. 1, pp. 154159, 2011.

[47] J. C. Frisvad, "Halotolerant and halophilic fungi and their extrolite production," in Adaptation to Life at High Salt Concentrations in Archaea, Bacteria and Eukarya, N. GundeCimerman, A. Oren, and A. Plemenitaš, Eds., pp. 426-440, Springer, Amsterdam, The Netherlands, 2005.

[48] A. Abdel-Raheem and C. A. Shearer, "Extracellular enzyme production by freshwater ascomycetes," Fungal Diversity, vol. 11, pp. 1-19, 2002. 

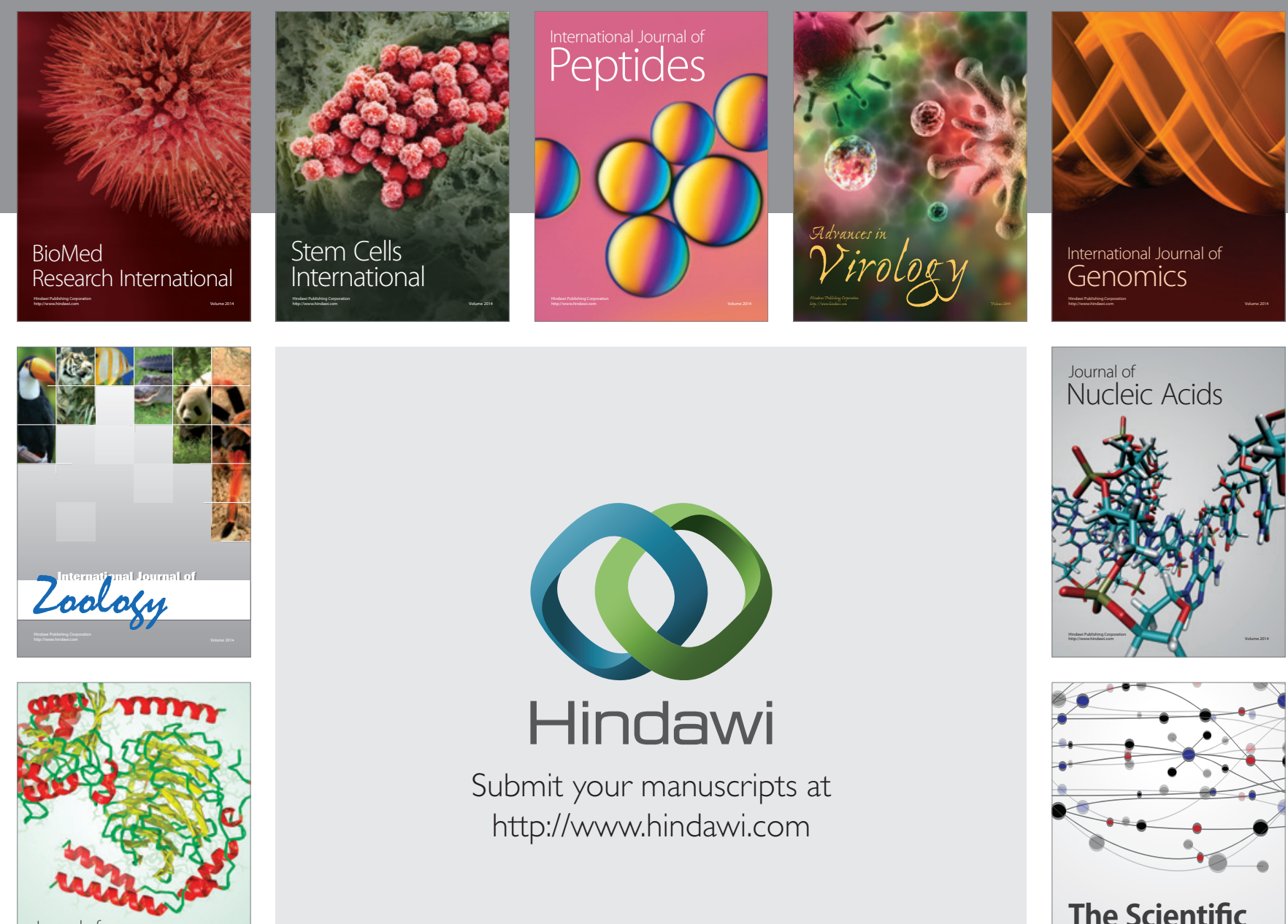

Submit your manuscripts at

http://www.hindawi.com

Journal of
Signal Transduction
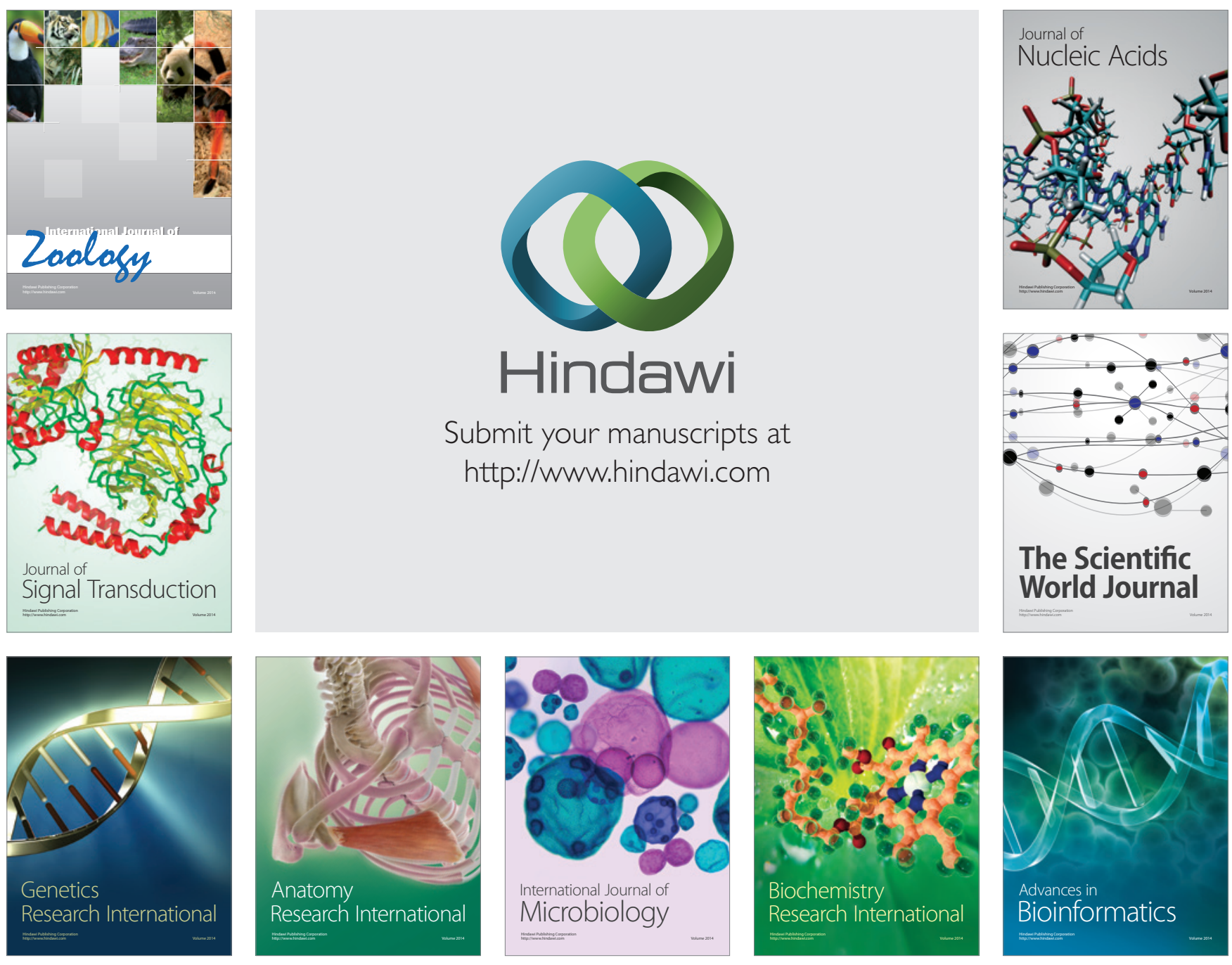

The Scientific World Journal
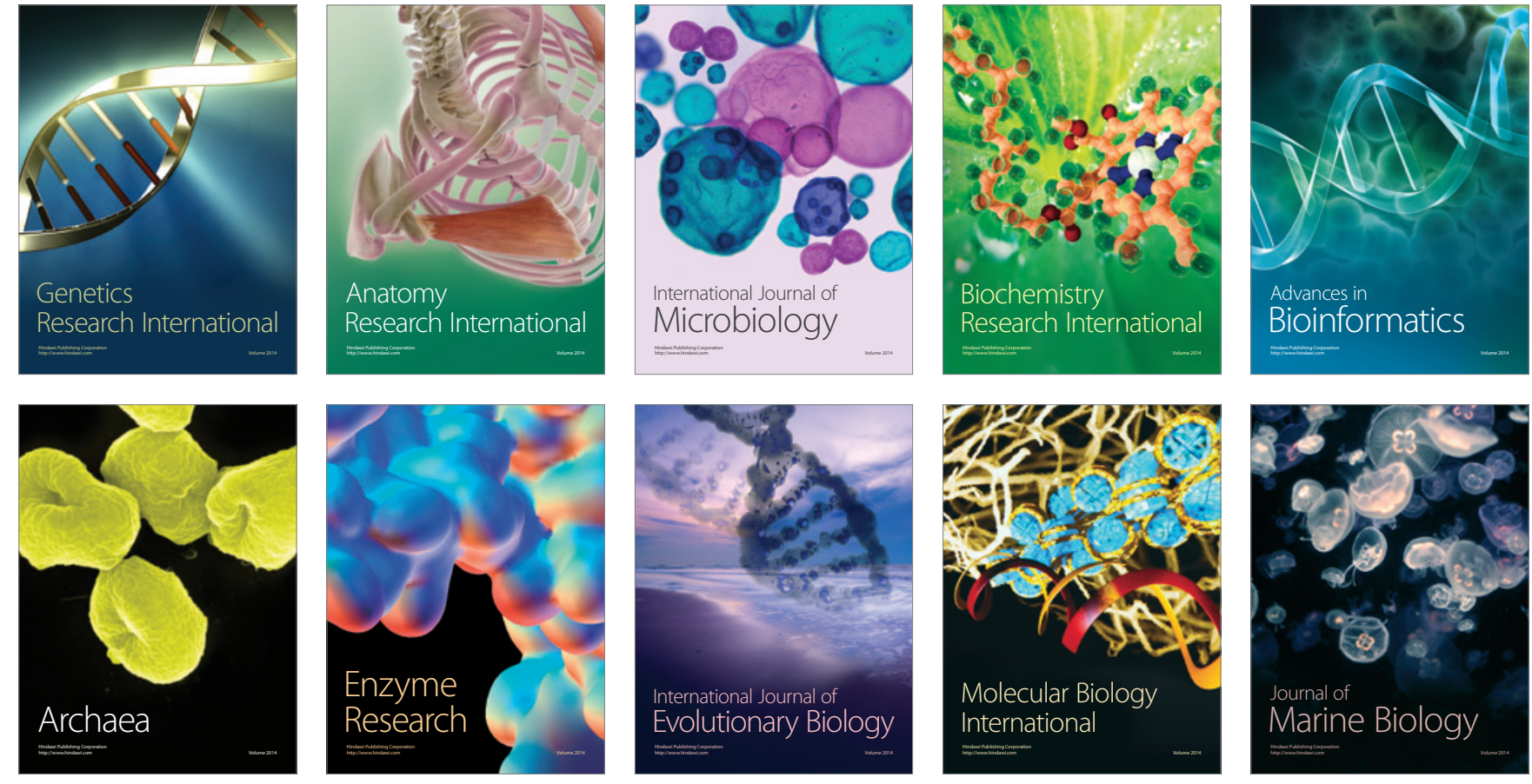